\title{
FRK wt Allele
}

National Cancer Institute

\section{Source}

National Cancer Institute. FRK wt Allele. NCI Thesaurus. Code C51115.

Human FRK wild-type allele is located within 6q21-q22.3 and is approximately $119 \mathrm{~kb}$ in length. This allele, which encodes tyrosine-protein kinase FRK protein, plays a role in cell cycle inhibition at the G1/S checkpoint and negative regulation of cell growth putatively via phosphorylation of perinuclear proteins. 